\title{
The Role of P2X7 Receptor in Infectious Inflammatory Diseases and the Influence of Ectonucleotidases
}

\author{
Ana Carolina Morandini ${ }^{1,2}$, Luiz Eduardo Baggio Savio ${ }^{1,2}$, Robson Coutinho-Silva ${ }^{1,2}$
}

\begin{abstract}
The purinergic receptor P2X ligand-gated ion channel 7 (P2X7) is ubiquitously expressed in almost all tissues and organs of the body with the highest distribution in the immune cells of monocyte-macrophage origin. Classically, $\mathrm{P} 2 \mathrm{X} 7$ receptor is involved in apoptotic cell death, and it is well known that extracellular ATP ligation to this purinergic receptor serves as an important secondary stimulus, which is also considered as danger signal for the interleukin (IL)-1 $\beta$ cleavage and secretion from pro-inflammatory cells. More recently, however, there has been substantial evidence of additional roles for the P2X7 receptor, both in innate immune response and as an adaptive link, including T-cell activation in a chronic state of inflammation. Also, compelling evidences have revealed an important role for ectonucleotidases as ATP-consuming

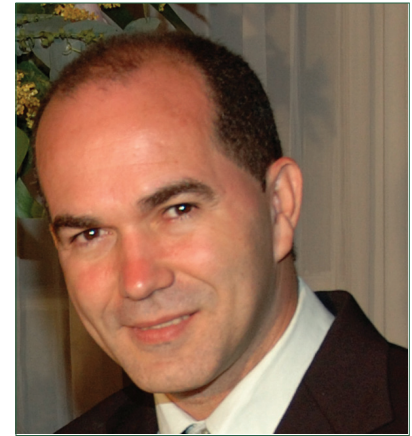

Prof. Robson Coutinho-Silva enzymes in the control and fine-tuning of P2X7 function by regulating the time, concentration, and availability of ATP during infection-driven inflammation. This review focuses on the current evidences for P2X7 receptor involvement in the initial stages of inflammation, as well as for its role in acute and chronic stages of infection. Here, we also highlight the role of ectonucleotidase family in the control of P2X7 function, including the initial and resolution phases of inflammation. (Biomed J 2014;37:169-177)
\end{abstract}

\section{Key words: ectonucleotidases, infection, inflammation, $\mathrm{P} 2 \mathrm{X} 7$ receptor}

\section{P2X7 as a starting point for inflammation}

$\mathrm{W}$ hen the body is challenged by pathogens during infections, the first-line defense for the host is provided by the innate immune system which encompasses various cell types such as macrophages, dendritic cells (DCs), and natural killer (NK) cells. These cells express the so-called pattern recognition receptors (PRRs) including Toll-Like receptors (TLRs), NOD-like receptors (NLRs), and RIG-I-like receptors (RLRs) on their surface and can recognize pathogen-associated molecular patterns (PAMPs) of bacterial and viral pathogens. ${ }^{[1,2]}$ After recognition of PAMPs by PRRs, diverse signaling pathways can be initiated resulting in the induction of pro- and anti-inflammatory cytokines and chemokines, which are essential for the host defense. Current literature evidence suggests a relationship between the cellular immune reaction and its regulation by cellular stress pathways, often activated in infections and chronic diseases as survival mechanisms activated by cells in response to stressful stimuli, as reviewed elsewhere. ${ }^{[3]}$

In this context, some endogenous intracellular molecules from the host can be secreted into the extracellular environment and they control the function of immune cells under pathological situations. During inflammatory conditions, extracellular ATP, which is classically associated with cellular energy metabolism, is often reported to be released passively following cellular stress or cell death. Extracellular ATP and the related purine and pyrimidine nucleotides exert their functions via signaling through membrane-bound purinergic $\mathrm{P} 2$ receptors. These receptors are widely expressed throughout the body on various immune and non-immune

From the ${ }^{1}$ Immunobiology Program, Institute of Biophysics Carlos Chagas Filho, Federal University of Rio de Janeiro, Rio de Janeiro, RJ, Brazil; ${ }^{2}$ National Institute of Science and Technology for Translational Research in Health and Environment in the Amazon Region (INPeTAm), Rio de Janeiro, RJ, Brazil

Received: Nov. 19, 2013; Accepted: Feb. 06, 2014

Correspondence to: Prof. Robson Coutinho-Silva, Institute of Biophysics Carlos Chagas Filho - UFRJ, RJ, Brazil. Centro de Ciências da Saúde, Bloco G., Av. Carlos Chagas Filho, 373, Cidade Universitária, Ilha do Fundão, Rio de Janeiro, RJ, 21941-902, Brazil. Tel: 55-21-25626565; Fax: 55-21-22808193; E-mail: rcsilva@biof.ufrj.br

DOI: $10.4103 / 2319-4170.127803$ 
cells. ${ }^{[4]}$ The $\mathrm{P} 2$ receptors are subdivided into two families: the G protein-coupled P2Y receptors and P2X receptors with ligand-gated ion channels..$^{[5,6]}$

The purinergic receptor $\mathrm{P} 2 \mathrm{X}$ ligand-gated ion channel 7 (P2X7) is ubiquitously expressed in almost all tissues and organs of the body, ${ }^{[4]}$ with the highest distribution in the immune cells of monocyte-macrophage origin. ${ }^{[7]}$ Besides the immune cells that are committed with critical protective responses since the early phases of microbial infection or acute tissue trauma, $\mathrm{P} 2 \mathrm{X} 7$ receptor has also been reported to be present in fibroblasts,,${ }^{[8]}$ endothelial cells,${ }^{[9]}$ exocrine glands (salivary glands and pancreas) ${ }^{[10]}$ as well as in epithelial cells. ${ }^{[1]]}$ In fact, once activated by extracellular ATP, the P2X7 receptor opens a nonselective cationic channel that allows $\mathrm{K}^{+}$efflux and $\mathrm{Na}^{+}$and $\mathrm{Ca}^{2+}$ influx. The activation of $\mathrm{P} 2 \mathrm{X} 7$ receptor is also associated with pore formation depending on the concentration and time of ATP treatment and the cell type. ${ }^{[4,12]}$

Continuous stimulation of $\mathrm{P} 2 \mathrm{X} 7$ receptor leads to apoptotic cell death in some cell types such as DCs and macrophages. ${ }^{[13,14]}$ Furthermore, a variety of downstream events have been described following P2X7 activation by its ligand, although these events require cell surface ATP levels $>100 \mu \mathrm{M}$ sustained over a few minutes. ${ }^{[15]}$ In cells previously primed by bacterial products, $\mathrm{P} 2 \mathrm{X} 7$ receptor activation functions as a co-stimulus or as a second signal for the formation of NOD-like receptor protein 3 (NALP3) inflammasome ${ }^{[16]}$ and secretion of interleukin (IL)-1 $\beta$ and IL-18, ${ }^{[17]}$ production of reactive oxygen species, ${ }^{[18]}$ and activation of nuclear factor kappa B (NF- $\kappa B) .{ }^{[19]}$

In the first stage of inflammation, extracellular ATP mainly functions as a pro-inflammatory and immunostimulatory mediator in the microenvironment of damaged/ injured cells. The ATP may be part of a group of endogenous molecules, the so called "alarmins." ${ }^{[20,21]}$ These multifunctional molecules seem to act as a particular subgroup of endogenous danger signals since they exhibit both chemotactic and activating effects on leukocytes, displaying potent innate immune-enhancing activity. ${ }^{[20]}$ ATP is present in the cell cytoplasm at millimolar concentrations, and is secreted during cellular stress or TLR activation, or is released in non-physiological necrotic cell death. ${ }^{[22-24]}$ Extracellular ATP concentrations in the local inflammatory microenvironment of damaged cells can be markedly upregulated, contributing to the promotion of sustained inflammation and the initiation of primary immune responses. In other words, ATP, at high extracellular concentration, appears to be a natural endogenous adjuvant released from injured and dying cells, which initiates inflammation and has an exacerbating effect to amplify and sustain cell-mediated immunity through P2 receptor-mediated purinergic signaling. At an early phase following cell damage, when extracellular ATP levels are the highest, the $\mathrm{P} 2$ receptor that is most likely associated in sensing the purinergic danger is the $\mathrm{P} 2 \mathrm{X} 7$ receptor, as previously reviewed. ${ }^{[25]}$

In different inflammatory models, lack of P2X7 receptor was described to be involved in neutrophil recruitment deficiency, as demonstrated using P2X7 knockout mice in different situations. P2X7 receptor was reported to be involved in polymorphonuclear and mast cell recruitment and macrophage activation in a mouse model of lung injury, ${ }^{[26]}$ and was also required for neutrophil accumulation in a mouse model of irritant contact dermatitis. ${ }^{[26,27]}$ Classically, P2X7 receptor would not be directly involved in polymorphonuclear leukocytes (PMNs) chemotaxis; but during bacterial challenge, ATP would be one of the mediators being secreted by both infected/stressed cells and bacteria. Expression of the P2X7 receptor actually enhances ATP release. ${ }^{[28]}$ In this context, the release of ATP could facilitate neutrophil recruitment to the site of infection by (A) directly enhancing neutrophil chemotaxis, (B) inducing chemokine secretion by macrophages through the activation of $\mathrm{P} 2 \mathrm{Y}$ receptors, and (C) inducing NLRP3 inflammasome activation and IL-1 $\beta$ secretion via $\mathrm{P} 2 \mathrm{X} 7$ receptor, as proposed recently. ${ }^{[23]}$ It was also demonstrated that ATP can be released by pannexin-1 hemichannels and that the autocrine feedback could happen by ATP ligation to P2Y2 receptor. ${ }^{[2]]}$ The ATP-P2Y2 ligation was shown to be involved in CXCL8 production (classically involved in neutrophil chemotaxis), which can be regulated by ectonucleotidases ${ }^{[30,31]}$ since these enzymes can control extracellular ATP availability [Figure 1].

\section{The role of $\mathrm{P} 2 \mathrm{X} 7$ in acute infection}

It was hypothesized in a recent study that $\mathrm{P} 2 \mathrm{X} 7$ receptor activation is the initial event leading to vascular dysfunction following lipopolysaccharide (LPS) treatment. It was also suggested that P2X7 receptor activation involves an initial upstream mechanism of LPS-induced vascular dysfunction, which is associated with IL- $1 \beta$-mediated endothelial nitric oxide synthase (eNOS), cyclooxygenase-2 (COX2) activation, and tumor necrosis factor alpha (TNF- $\alpha$ ) release. ${ }^{[32]}$ It has also been demonstrated that purinergic signaling in the skin induces innate inflammation, leading to the differentiation of human T helper 17 (Th17) responses, which have implications in the pathogenesis and potential treatment of diseases, for example, psoriasis. ${ }^{[33]}$

The influence of bacterially released ATP in the differentiation of Th17 cells in the intestinal mucosa was previously examined. ${ }^{[34]}$ The delicate balance between the immune system and infectious agents requires a number of cellular players, in particular Th17 cells, which mediate an inflammatory response and are normally controlled by the simultaneous presence of regulatory T cells (Tregs). ${ }^{[35]}$ The referred study showed that commensal bacteria can 


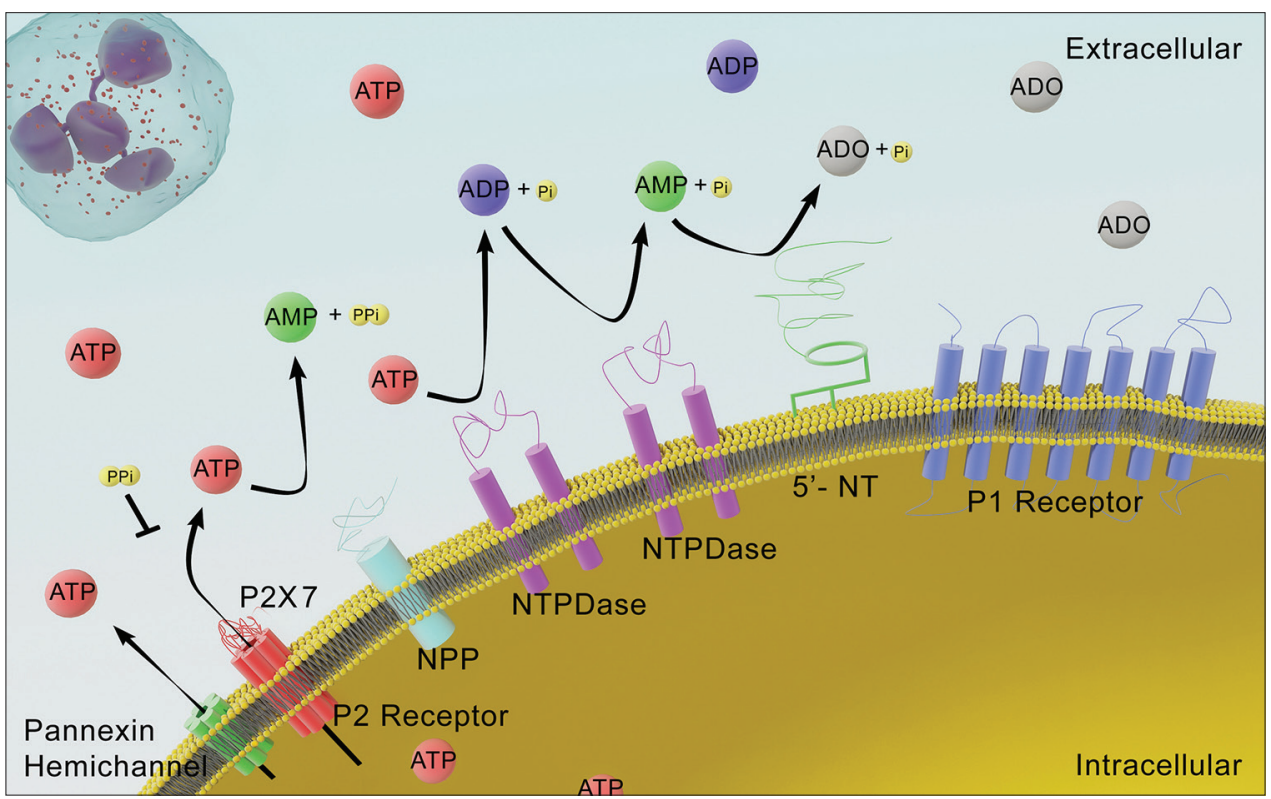

Figure 1: Schematic representation of purinergic signaling and extracellular nucleotide-metabolizing pathways. P2X7 receptor can be activated by ATP released from immune and non-immune cells under pathological conditions such as inflammation and infection. The P2X7 receptor activation induces a massive ATP release that can occur through pannexin hemichannel. Extracellular ATP acts as a danger signal that can play a role in the recruitment of inflammatory cells such as neutrophils. Extracellular ATP can also be the substrate for nucleotidemetabolizing enzymes (ectonucleotidases). NPPs hydrolyze tri- and diphosphonucleosides, releasing pyrophosphates, which can impair the P2X7 functionality. NTPDases hydrolyze ATP to ADP and ADP to AMP. Finally, the 5'-NT (CD73) hydrolyzes AMP, producing adenosine, which can act by P1 receptors. Abbreviations: ADO: Adenosine; 5'-NT: 5'-Nucleotidase; NPP: Nucleotide pyrophosphatase/phosphodiesterase; NTPDases: Nucleoside triphosphate diphosphohydrolases.

release large amounts of ATP (although not sufficient to deliver a "danger" inflammatory signal to the intestinal mucosa). The percentage of Th17 cells in bacteria-free mice was upregulated by treating them with adenosine 5'-O-(3-thiotriphosphate), a nonhydrolyzable form of ATP, or decreased by treatment with apyrase, which degrades ATP. The percentage of Th17 cells measured in a co-culture of $\mathrm{T}$ cells and DCs was strongly increased by the addition of bacterial supernatant, and this effect was apyrase dependent, demonstrating that Th17 cell differentiation is markedly influenced by bacterially dependent ATP in the intestinal mucosa.

Accordingly, the ATP released by activated Tregs triggered a decrease in the Foxp3 protein (a Treg-associated transcription factor) and polarized the cells susceptible of conversion to Th17 cells through the activation of $\mathrm{P} 2 \mathrm{X} 7$ receptors. This supports a role for autocrine ATP in modulating Treg-mediated immunosuppression and lineage stability, and in acting on the fine-tuning of the developmental and immunosuppressive program of the $\mathrm{T}$ cells in adaptive immune responses. ${ }^{[36]}$ In a direct manner, $\mathrm{P} 2 \mathrm{X} 7$ receptor was shown to be effectively involved in T-cell activation since the ATP release was required for TCR-mediated calcium influx and IL-2 production. Using Jurkat T cells, the removal of extracellular ATP by apyrase or the use of small interfering RNA (siRNA) silencing of P2X7 receptors blocked calcium influx and, consequently, inhibited T-cell activation. ${ }^{[37]}$ The same group of researchers also demonstrated that pannexin-1 hemichannels, together with $\mathrm{P} 2 \mathrm{X} 1$ and $\mathrm{P} 2 \mathrm{X} 4$ receptors facilitated ATP release and calcium entry, thus regulating T-cell activation. ${ }^{[38]}$

Besides other functions, the $\mathrm{P} 2 \mathrm{X} 7$ receptor seems to regulate the uptake of foreign particles or bacteria, and after a few minutes, extracellular ATP increases, firstly to limit excessive phagocytosis by the macrophage and secondly to promote the release of pro-inflammatory cytokines. ${ }^{[39]}$ It was demonstrated that $\mathrm{P} 2 \mathrm{X} 7$ receptor controls Chlamydia infection, for example, by directly inhibiting the infection in epithelial cells, rather than by the ability of $\mathrm{P} 2 \mathrm{X} 7$ receptor to modulate IL- $1 \beta$ secretion. ${ }^{[40]}$

Regarding specific bacterial infections such as those of Mycobacteria and Chlamydia, activated P2X7 receptor has been shown to be able to control the pathogen. ${ }^{[41-44]}$ Specifically in these models, P2X7 activation led to infection inhibition through fusion of vacuoles with lysosomes, which has been shown to promote vacuole acidification, a mechanism that needs the activation of host cell phospholipases. ${ }^{[42]} \mathrm{Also}$, in macrophages infected with the protozoan Toxoplasma gondii, ATP was shown to mediate pathogen elimination through acidification of the parasitophorous vacuole. ${ }^{[45,46]}$ Also, it was reported that in Leishmania amazonensis infection of macrophages, a P2X7 receptor upregulation was induced, which, when activated by ATP, reduced the pathogen load and, consequently, the cell death. ${ }^{[47]}$ It was 
shown that the control of L. amazonensis infection mediated by $\mathrm{P} 2 \mathrm{X} 7$ receptor activation involves production of leukotriene B4 (LTB4) by a mechanism dependent on the enzyme, 5-lipoxygenase (unpublished data). Recently, a study using a macrophage-epithelial cell co-culture system during viral infection has demonstrated that ATP signaling through $\mathrm{P} 2 \mathrm{X} 7$ receptor is required for the induction of inflammatory mediators by inflammasome activation, since inhibition or deficiency of P2X7, as well as caspase-1, significantly reduces IL- $1 \beta$ secretion. ${ }^{[48]}$

In relation to $\mathrm{P} 2 \mathrm{X} 7$ function regulation, a $\mathrm{P} 2 \mathrm{X} 7$ variant with apoptosis inhibitory actions has already been identified in humans, which demonstrated a distinct regulatory property for a truncated variant to antagonize its full-length counterpart through hetero-oligomerization. This was suggested to represent a possibility for regulation of a protein function by its variant. ${ }^{[49]}$ It was demonstrated that interferon-gamma (IFN- $\gamma$ ) treatment, inducing a pro-inflammatory state in HeLa cells, was associated with a change in the functional state of the $\mathrm{P} 2 \mathrm{X} 7$ receptor, upregulating the expression of its functional variant and downregulating the expression of truncated form. ${ }^{[50]}$ Also, in a cancer study utilizing the chemotherapeutic agent Anthracycline, individuals treated for breast cancer and carrying a loss-of-function allele of P2X7 receptor developed metastatic disease more rapidly than the individuals presenting the normal allele. ${ }^{[51]}$ Conditions linked to $\mathrm{P} 2 \mathrm{X} 7$ receptor gene polymorphisms include tuberculosis susceptibility, resistance to infection by Chlamydia trachomatis, and increased fracture risk in post-menopausal women. ${ }^{[52]}$

\section{The modified role of $\mathbf{P} 2 X 7$ in chronic infection}

It is well known that ATP ligation to P2X7 receptors serves as an important secondary stimulus for the IL- $1 \beta$ cleavage and secretion from pro-inflammatory cells, as previously reviewed elsewhere. ${ }^{[21]}$ Furthermore, P2X7 receptor activation may function as a danger signal in the context of tissue trauma. ${ }^{[53]}$ However, the role of P2X7 in the chronic exposure to ATP and chronic infection is still poorly explored. Chronic exposure to low (micromolar) concentrations of extracellular ATP might work as a negative feedback to impair dendritic cells' contribution to exacerbated inflammation. In the proximity of injured cells, where the concentration may be in the micromolar range, ATP can block the synthesis of pro-inflammatory cytokines and chemokines by the DCs required for the recruitment of NK cells and type 1 polarized T cells. In other words, this can restrict dendritic cells' capacity to induce a Th1 response. As a result, the development of less self-harmful type 2 responses is privileged. ${ }^{[53]}$

In an in vivo model of diabetes mellitus, the expression of P2X7 in the pancreas of early- and late-developed diabetes was investigated. ${ }^{[54]} \mathrm{A}$ differential pattern of P2X7 receptor expression was found, since in early-developed diabetes, $\mathrm{P} 2 \mathrm{X} 7$ receptor expression changed from an annular expression around the pancreatic islets to a more diffuse pattern. In late-developed diabetes, P2X7 receptors were downregulated. ${ }^{[54]} \mathrm{P} 2 \mathrm{X} 7$ receptor role was also evaluated in the process of interstitial inflammation and fibrosis, tubular atrophy, and renal cell apoptosis. ${ }^{[55]}$ This study highlighted the involvement of these receptors in the process of interstitial inflammation and collagen deposition in response to ureteral obstruction, indicating that $\mathrm{P} 2 \mathrm{X} 7$ receptor can be upregulated in the initial stages of renal inflammation but downregulated as the chronic obstruction persists. ${ }^{[55]}$ In accordance with this, recent data also showed a downregulation of $\mathrm{P} 2 \mathrm{X} 7$ receptor in schistosomiasis infection, an intravascular disease associated with inflammation, which likely limits the infection-related endothelial damage. ${ }^{[56]}$

Using both in vitro and in vivo models, colchicine has been documented to block the pro-inflammatory signaling downstream of $\mathrm{P} 2 \mathrm{X} 7$ receptor activation. It was suggested that the dye uptake associated with the activation of $\mathrm{P} 2 \mathrm{X} 7$ receptors is distinct from the $\mathrm{P} 2 \mathrm{X} 7$ receptor ion channel and could be a therapeutic target for the treatment of chronic inflammation. ${ }^{[57]}$ Recent studies using gene knockout mice and selective $\mathrm{P} 2 \mathrm{X} 7$ receptor antagonists suggest that $\mathrm{P} 2 \mathrm{X} 7$ receptor is a viable therapeutic target for inflammatory diseases. However, efficacious P2X7 receptor antagonists for use in clinical studies are still at an early stage of development. Future challenges include identifying the potential toxicity and side effects of the P2X7 antagonists, as well as their duration in chronic inflammatory conditions, as reviewed elsewhere. ${ }^{[58]}$

\section{The role of ectonucleotidases in the P2X7 functionality in inflammation and infection}

Since ATP and other nucleotides (e.g. UTP and $\mathrm{NAD}+$ ) are released from immune and non-immune cells during inflammation, infection, and tissue damage, ${ }^{[25,59-61]}$ the presence of nucleotide-metabolizing pathways on the surface of these cells is essential for the sophisticated regulation of the composition, duration, intensity, and magnitude of purinergic signaling. ${ }^{[62]}$ The proteins located on the cell surface which are responsible for this control of purinergic signaling are a group of enzymes named ectonucleotidases. The ecto-nucleoside triphosphate diphosphohydrolases (E-NTPDases), ecto-nucleotide pyrophosphatase/phosphodiesterases (E-NPPs), and ecto- 5 '-nucleotidase are the most relevant ectonucleotidases in the innate immunity context ${ }^{[63,64]}$ [Figure 1] and are discussed in this review. 


\section{Ecto-nucleoside triphosphate diphosphohydrolases}

E-NTPDases hydrolyze extracellular tri- and diphosphonucleosides to monophosphonucleosides, and eight different enzymes are described as members of this family. ${ }^{[65]}$ NTPDase1/CD39, NTPDase2/CD39L1, NTPDase3/ CD39L3, and NTPDase8 are ectoenzymes tightly bounded to the plasma membrane through two transmembrane domains. ${ }^{[63,66]}$ On the other hand, the NTPDase4, NTPDase5, NTPDase6, and NTPDase7 show intracellular localization. Among them, NTPDase5 and NTPDase6 present only an $\mathrm{N}$-terminal transmembrane domain described as a possible cleavage site; therefore, these intracellular NTPDases can be shed and released into the extracellular medium. ${ }^{[64,67,68]}$ E-NTPDase 1 hydrolyzes ATP and ADP equally well, while E-NTPDases2, 3, and 8 prefer to hydrolyze ATP over ADP. Of note, E-NTPDase1/CD39 is the dominant ectonucleotidase in immune cells, while E-NTPDase8 is highly expressed only in the liver, kidney, and jejunum. ${ }^{[63,69]}$

Since ATP pro-inflammatory signaling through P2X7 receptor can be terminated by the action of E-NTPDases, a role for these enzymes in inflammation and infection has become more accepted over the last few years. Different groups have reported the importance of E-NTPDases in regulating the extracellular nucleotide levels and, consequently, the P2 receptor activities during inflammatory conditions. ${ }^{[62,70]}$ Levesque et al..${ }^{[71]}$ demonstrated that E-NTPDase1/CD39 is the major ectonucleotidase expressed in macrophages, and that this enzyme can modulate in vitro cellular responses, such as apoptosis and IL- $1 \beta$ and IL- 18 release, through P2X7 receptor activation. Also, Zanin et al., ${ }^{[72]}$ have shown that the activity and gene expression of E-NTPDases decrease in pro-inflammatory M1 macrophages, suggesting an accumulation of extracellular ATP, which is relevant for NLRP3 inflammasome activation and IL- $1 \beta$ release. By contrast, M2 macrophages showed an increased nucleotide catabolism and E-NTPDases expression, reducing the ATP availability and generating an adenosine-rich immunosuppressive environment. Recently, Cohen et al., ${ }^{[22]}$ also reported that the TLR receptor activation induces ATP release, which is rapidly broken down into adenosine by E-NTPDase1/CD39, reducing the macrophage activation. Also, using a mouse model of sepsis, the same authors demonstrated the importance of ATP hydrolysis during inflammatory responses, where E-NTPDase1-deficient macrophages induce lethal endotoxic shock. Furthermore, Téâtre et al. ${ }^{[73]}$ showed that the overexpression of CD39 in airway epithelia can protect against $P$ seudomonas aeruginosa infection, thus providing evidences that E-NTPDases are also crucial to prevent the desensitization of $\mathrm{P} 2$ receptors, since high extracellular nucleotide levels may induce this phenomenon and, consequently, impair a pro-inflammatory response through the activation of these receptors. Therefore, these reports suggest that the functionality of ectonucleotidases impacts the macrophage functions and that a sophisticated control of E-NTPDase activities is essential for a beneficial immune response during inflammation and infection.

The extracellular ATP acting through P2X7 receptor plays a key role in the host resistance to infection by microbial pathogens, as discussed earlier. Interestingly, several reports have shown that pathogens can exploit the host cell ectonucleotidases, which scavenge extracellular ATP, reducing the microbicidal responses triggered by $\mathrm{P} 2 \mathrm{X} 7$ receptor activation. ${ }^{[74]}$ Studies have reported an increase in E-NTPDases' activity and expression in lymphocytes of patients infected with human immunodeficiency virus, ${ }^{[75,76]}$ as well as in endothelial cells infected with cytomegalovirus. ${ }^{[77]}$ Moreover, studies have shown that several pathogens express ectonucleotidases, which favors their invasion and dissemination in the host. Firstly, Crane et al. ${ }^{\left[{ }^{[78]}\right.}$ demonstrated a rapid breakdown of the released ATP in response to enteropathogenic Escherichia coli infection. Sansom et al. ${ }^{[79]}$ reported that the bacteria Legionella pneumophila are equipped with an E-NTPDase similar to human CD39, which facilitates the entry of the bacteria in host macrophages and epithelial cells. Also, Zebisch et al. ${ }^{[80]}$ recently reported a new crystal form of E-NTPDase 1 in this bacterium. Porphyromonas gingivalis, in turn, secretes a homolog of nucleoside diphosphate kinase (Ndk), which can inhibit P2X7-mediated apoptosis in macrophages or primary gingival epithelial cells. ${ }^{[81,82]}$ Secondly, fungi, such as Saccharomyces cerevisiae, Candida parapsilosis, and Cryptococcus neoformans that can cause pneumonia and meningoencephalitis, also have ectoenzymes that hydrolyze ATP and generate adenosine. Finally, E-NTPDase activities have been described in protozoan parasites belonging to the genera Leishmania, Trichomonas, Trypanosoma, and Toxoplasma, and the activities of these enzymes have been correlated to the establishment and propagation of these protozoan infections..$^{[83-86]}$

\section{Ecto-nucleotide pyrophosphatase/ phosphodiesterases}

E-NPP family presents seven structurally related ectoenzymes, but only the first three members (E-NPP1-3) are relevant in the context of the purinergic signaling cascade. These enzymes are able to hydrolyze pyrophosphate and phosphodiester bonds in a wide range of substrates, such as tri- and diphosphonucleosides, nucleic acids, nucleotide sugars, as well as in choline phosphate esters and lysophospholipids. ${ }^{[87,88]}$

Studies have suggested that the E-NPPs also play an important role in the modulation of purinergic signaling during inflammation by hydrolyzing extracellular 
pro-inflammatory nucleotides and generating extracellular pyrophosphates. ${ }^{[87,89]}$ Pelegrin and Suprenant demonstrated that pyrophosphates can inhibit caspase- 1 activation and IL-1 $\beta$ release, ${ }^{[90]}$ suggesting that these molecules are able to block the inflammasome activation. In addition, pyrophosphates reduce the pro-inflammatory cytokine production during peritonitis. ${ }^{[11]}$ Interestingly, the E-NPP activities and gene expression increase 24 and $48 \mathrm{~h}$ after the LPS-induced endotoxemia in mice lymphocytes and kidney membrane preparations. ${ }^{[92,93]}$ Moreover, a recent study showed that the E-NPP activities increase in the platelets of patients with indeterminate form of Chagas' disease, indicating the role of these enzymes in protozoan pathogens invading the bloodstream. ${ }^{[94]}$ By contrast, Vuaden et al.,$^{\left[{ }^{[5]}\right]}$ demonstrated that $48 \mathrm{~h}$ of induced endotoxemia promotes a decrease in E-NPP activities in rat platelets and a reduction in platelet aggregation. Finally, Lopez-Castejón et al..${ }^{[91]}$ reported that the NPP-1 is highly expressed in M2 compared to M1 macrophages, while an exacerbated NPP-2 (autotaxin) and NPP-3 expression is associated with several types of cancer. ${ }^{[96-98]}$ Taken together, these reports might suggest that E-NPPs can impair the $\mathrm{P} 2 \mathrm{X} 7$ receptor functionality and contribute to the resolution of inflammation by producing extracellular pyrophosphates.

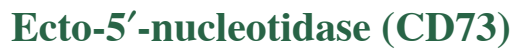

The ecto- $5^{\prime}$-nucleotidase/CD73 is a glycosylphosphatidylinositol-anchored enzyme responsible for AMP hydrolysis, thus generating adenosine, the final product of ATP breakdown. ${ }^{[99]}$ Ecto-5'-nucleotidase (CD73) is classically a lymphocyte maturation marker which is involved in intracellular signaling, lymphocyte proliferation and activation. ${ }^{[100,101]}$ Although ecto-5'-nucleotidase/CD73 is not directly related to the $\mathrm{P} 2 \mathrm{X} 7$ receptor functionality, the opposing effects of adenosine and ATP on the immune cells suggest an important role for this enzyme in innate immunity context. Importantly, different authors have reported that this enzyme can also modulate macrophage, neutrophil, and dendritic cell functions. ${ }^{[30,72,100,102]}$ Regarding this, several studies have demonstrated the importance of ecto- 5 '-nucleotidase/ CD73 in generating an adenosine-rich environment in inflammation and infection, as detailed further in several recent reviews. ${ }^{[62,70,103]}$

\section{Concluding remarks}

P2X7 receptor has been widely investigated, especially with regard to its participation in the innate immune response. Much of the recent data in the literature provides evidence showing that this receptor is not only involved in pore formation and control of cellular apoptosis, but also can actively act together with other mediators in the initia- tion of inflammation, control of infection, and regulation of adaptive T-cell activation. The fine-tuning of $\mathrm{P} 2 \mathrm{X} 7$ receptor function is markedly affected by the time of exposure and quantity of extracellular ATP which is shown to be tightly regulated by the action of ectonucleotidases. As such, P2X7 receptor not only represents an interesting therapeutic target in infectious inflammatory diseases, but also continues to represent a focus for future research regarding its regulation by these ectoenzymes, which in turn can direct the course of inflammation.

\section{Acknowledgments}

This work was supported by funds from the Conselho Nacional de Desenvolvimento Cientifico e Tecnológico do Brasil (CNPq), Coordenação de Aperfeiçoamento de Pessoal de Nível Superior (CAPES), the Programa de Núcleos de Excelência (PRONEX), Fundação de Amparo à Pesquisa do Estado do Rio de Janeiro (FAPERJ), and the Instituto Nacional de Ciência e Tecnologia para Pesquisa Translacional em Saúde e Ambiente na Região Amazônica INPeTAm/ UFRJ). This study was approved and partially funded by Ciências sem Fronteiras Federal Government Program with post-doctoral scholarship to ACM.

\section{REFERENCES}

1. Akira S, Takeda K, Kaisho T. Toll-like receptors: Critical proteins linking innate and acquired immunity. Nat Immunol 2001;2:675-80.

2. Kumar H, Kawai T, Akira S. Pathogen recognition by the innate immune system. Int Rev Immunol 2011;30:16-34.

3. Muralidharan S, Mandrekar P. Cellular stress response and innate immune signaling: Integrating pathways in host defense and inflammation. J Leukoc Biol 2013;94:1167-84.

4. Burnstock G, Knight GE. Cellular distribution and functions of P2 receptor subtypes in different systems. Int Rev Cytol 2004;240:31-304.

5. Abbracchio MP, Burnstock G, Boeynaems JM, Barnard EA, Boyer JL, Kennedy C, et al. International Union of Pharmacology LVIII: Update on the P2Y G protein-coupled nucleotide receptors: From molecular mechanisms and pathophysiology to therapy. Pharmacol Rev 2006;58:281-341.

6. Ralevic V, Burnstock G. Receptors for purines and pyrimidines. Pharmacol Rev 1998;50:413-92.

7. Gu BJ, Zhang WY, Bendall LJ, Chessell IP, Buell GN, Wiley JS. Expression of P2X(7) purinoceptors on human lymphocytes and monocytes: Evidence for nonfunctional P2X(7) receptors. Am J Physiol Cell Physiol 2000;279:C1189-97.

8. Montreekachon P, Chotjumlong P, Bolscher JG, Nazmi K, Reutrakul V, Krisanaprakornkit S. Involvement of P2X(7) purinergic receptor and MEK1/2 in interleukin-8 up-regulation by LL-37 in human gingival fibroblasts. J Periodontal Res 2011;46:327-37.

9. Wilson HL, Varcoe RW, Stokes L, Holland KL, Francis SE, Dower SK, et al. P2X receptor characterization and IL-1/IL-1Ra release from human endothelial cells. Br J Pharmacol 2007;151:115-27. 
10. Novak I. Purinergic receptors in the endocrine and exocrine pancreas. Purinergic Signal 2008;4:237-53.

11. Souza CO, Santoro GF, Figliuolo VR, Nanini HF, de Souza HS, Castelo-Branco MT, et al. Extracellular ATP induces cell death in human intestinal epithelial cells. Biochim Biophys Acta 2012;1820:1867-78.

12. Jacob F, Perez Novo C, Bachert C, Van Crombruggen K. Purinergic signaling in inflammatory cells: $\mathrm{P} 2$ receptor expression, functional effects, and modulation of inflammatory responses. Purinergic Signal 2013;9:285-306.

13. Coutinho-Silva R, Perfettini JL, Persechini PM, Dautry-Varsat A, Ojcius DM. Modulation of $\mathrm{P} 2 \mathrm{Z} / \mathrm{P} 2 \mathrm{X}(7)$ receptor activity in macrophages infected with Chlamydia psittaci. Am J Physiol Cell Physiol 2001;280:C81-9.

14. Coutinho-Silva R, Persechini PM, Bisaggio RD, Perfettini JL, Neto AC, Kanellopoulos JM, et al. P2Z/P2X7 receptor-dependent apoptosis of dendritic cells. Am J Physiol 1999;276:C1139-47.

15. Surprenant A, Rassendren F, Kawashima E, North RA, Buell G. The cytolytic P2Z receptor for extracellular ATP identified as a P2X receptor (P2X7). Science 1996;272:735-8.

16. Mariathasan S, Weiss DS, Newton K, McBride J, O'Rourke K, Roose-Girma $\mathrm{M}$, et al. Cryopyrin activates the inflammasome in response to toxins and ATP. Nature 2006;440:228-32.

17. Piccini A, Carta S, Tassi S, Lasiglie D, Fossati G, Rubartelli A. ATP is released by monocytes stimulated with pathogen-sensing receptor ligands and induces IL-1beta and IL-18 secretion in an autocrine way. Proc Natl Acad Sci USA 2008;105:8067-72.

18. Cruz CM, Rinna A, Forman HJ, Ventura AL, Persechini PM, Ojcius DM. ATP activates a reactive oxygen species-dependent oxidative stress response and secretion of proinflammatory cytokines in macrophages. J Biol Chem 2007;282:2871-9.

19. Ferrari D, Wesselborg S, Bauer MK, Schulze-Osthoff K. Extracellular ATP activates transcription factor NF-kappaB through the P2Z purinoreceptor by selectively targeting NF-kappaB p65. J Cell Biol 1997;139:1635-43.

20. Oppenheim JJ, Yang D. Alarmins: Chemotactic activators of immune responses. Curr Opin Immunol 2005;17:359-65.

21. Said-Sadier N, Ojcius DM. Alarmins, inflammasomes and immunity. Biomed J 2012;35:437-49.

22. Cohen HB, Briggs KT, Marino JP, Ravid K, Robson SC, Mosser DM. TLR stimulation initiates a CD39-based autoregulatory mechanism that limits macrophage inflammatory responses. Blood 2013;122:1935-45.

23. Xiang Y, Wang X, Yan C, Gao Q, Li SA, Liu J, et al. Adenosine5 '-triphosphate (ATP) protects mice against bacterial infection by activation of the NLRP3 inflammasome. PLoS One 2013;8:e63759.

24. Loomis WH, Namiki S, Ostrom RS, Insel PA, Junger WG. Hypertonic stress increases T cell interleukin-2 expression through a mechanism that involves ATP release, P2 receptor, and p38 MAPK activation. J Biol Chem 2003;278:4590-6.

25. Bours MJ, Swennen EL, Di Virgilio F, Cronstein BN, Dagnelie PC. Adenosine 5'-triphosphate and adenosine as endogenous signaling molecules in immunity and inflammation. Pharmacol Ther 2006;112:358-404.

26. Moncao-Ribeiro LC, Cagido VR, Lima-Murad G, Santana PT, Riva DR, Borojevic R, et al. Lipopolysaccharide-induced lung injury:
Role of P2X7 receptor. Respir Physiol Neurobiol 2011;179:314-25.

27. da Silva GL, Sperotto ND, Borges TJ, Bonorino C, Takyia CM, Coutinho-Silva $\mathrm{R}$, et al. $\mathrm{P} 2 \mathrm{X} 7$ receptor is required for neutrophil accumulation in a mouse model of irritant contact dermatitis. Exp Dermatol 2013;22:184-8.

28. Pellegatti P, Falzoni S, Pinton P, Rizzuto R, Di Virgilio F. A novel recombinant plasma membrane-targeted luciferase reveals a new pathway for ATP secretion. Mol Biol Cell 2005;16:3659-65.

29. Chen Y, Yao Y, Sumi Y, Li A, To UK, Elkhal A, et al. Purinergic signaling: A fundamental mechanism in neutrophil activation. Sci Signal 2010;3:ra45.

30. Corriden R, Chen Y, Inoue Y, Beldi G, Robson SC, Insel PA, et al. Ecto-nucleoside triphosphate diphosphohydrolase 1 (E-NTPDase1/ CD39) regulates neutrophil chemotaxis by hydrolyzing released ATP to adenosine. J Biol Chem 2008;283:28480-6.

31. Kukulski F, Bahrami F, Ben Yebdri F, Lecka J, Martin-Satue M, Levesque SA, et al. NTPDase1 controls IL-8 production by human neutrophils. J Immunol 2011;187:644-53.

32. Chiao CW, da Silva-Santos JE, Giachini FR, Tostes RC, Su MJ, Webb RC. P2X7 receptor activation contributes to an initial upstream mechanism of lipopolysaccharide-induced vascular dysfunction. Clin Sci (Lond) 2013;125:131-41.

33. Killeen ME, Ferris L, Kupetsky EA, Falo L Jr, Mathers AR. Signaling through Purinergic Receptors for ATP Induces Human Cutaneous Innate and Adaptive Th17 Responses: Implications in the Pathogenesis of Psoriasis. J Immunol 2013;190:4324-36.

34. Atarashi K, Nishimura J, Shima T, Umesaki Y, Yamamoto M, Onoue $\mathrm{M}$, et al. ATP drives lamina propria $\mathrm{T}(\mathrm{H}) 17$ cell differentiation. Nature 2008;455:808-12.

35. Izcue A, Coombes JL, Powrie F. Regulatory T cells suppress systemic and mucosal immune activation to control intestinal inflammation. Immunol Rev 2006;212:256-71.

36. Schenk U, Frascoli M, Proietti M, Geffers R, Traggiai E, Buer J, et al. ATP inhibits the generation and function of regulatory T cells through the activation of purinergic P2X receptors. Sci Signal 2011;4:ra12.

37. Yip L, Woehrle T, Corriden R, Hirsh M, Chen Y, Inoue Y, et al. Autocrine regulation of T-cell activation by ATP release and P2X7 receptors. FASEB J 2009;23:1685-93.

38. Woehrle T, Yip L, Elkhal A, Sumi Y, Chen Y, Yao Y, et al. Pannexin-1 hemichannel-mediated ATP release together with P2X1 and P2X4 receptors regulate T-cell activation at the immune synapse. Blood 2010;116:3475-84.

39. Gu BJ, Saunders BM, Jursik C, Wiley JS. The P2X7-nonmuscle myosin membrane complex regulates phagocytosis of nonopsonized particles and bacteria by a pathway attenuated by extracellular ATP. Blood 2010;115:1621-31.

40. Darville T, Welter-Stahl L, Cruz C, Sater AA, Andrews CW Jr, Ojcius DM. Effect of the purinergic receptor P2X7 on Chlamydia infection in cervical epithelial cells and vaginally infected mice. J Immunol 2007;179:3707-14.

41. Biswas D, Qureshi OS, Lee WY, Croudace JE, Mura M, Lammas DA. ATP-induced autophagy is associated with rapid killing of intracellular mycobacteria within human monocytes/macrophages. BMC Immunol 2008;9:35.

42. Coutinho-Silva R, Stahl L, Raymond MN, Jungas T, Verbeke P, Burnstock $\mathrm{G}$, et al. Inhibition of chlamydial infectious activity 
due to P2X7R-dependent phospholipase D activation. Immunity 2003;19:403-12.

43. Kusner DJ, Barton JA. ATP stimulates human macrophages to kill intracellular virulent Mycobacterium tuberculosis via calciumdependent phagosome-lysosome fusion. J Immunol 2001;167:3308-15.

44. Santos AA Jr, Rodrigues-Junior V, Zanin RF, Borges TJ, Bonorino C, Coutinho-Silva $\mathrm{R}$, et al. Implication of purinergic $\mathrm{P} 2 \mathrm{X} 7$ receptor in M. tuberculosis infection and host interaction mechanisms: A mouse model study. Immunobiology 2013;218:1104-12.

45. Correa G, Marques da Silva C, de Abreu Moreira-Souza AC, Vommaro RC, Coutinho-Silva R. Activation of the P2X(7) receptor triggers the elimination of Toxoplasma gondii tachyzoites from infected macrophages. Microbes Infect 2010;12:497-504.

46. Lees MP, Fuller SJ, McLeod R, Boulter NR, Miller CM, Zakrzewski AM, et al. P2X7 receptor-mediated killing of an intracellular parasite, Toxoplasma gondii, by human and murine macrophages. J Immunol 2010;184:7040-6.

47. Chaves SP, Torres-Santos EC, Marques C, Figliuolo VR, Persechini PM, Coutinho-Silva R, et al. Modulation of P2X(7) purinergic receptor in macrophages by Leishmania amazonensis and its role in parasite elimination. Microbes Infect 2009;11:842-9.

48. Lee BH, Hwang DM, Palaniyar N, Grinstein S, Philpott DJ, Hu J. Activation of $\mathrm{P} 2 \mathrm{X}(7)$ receptor by ATP plays an important role in regulating inflammatory responses during acute viral infection. PLoS One 2012; 7:e35812.

49. Feng YH, Li X, Wang L, Zhou L, Gorodeski GI. A truncated P2X7 receptor variant (P2X7-j) endogenously expressed in cervical cancer cells antagonizes the full-length $\mathrm{P} 2 \mathrm{X} 7$ receptor through heterooligomerization. J Biol Chem 2006;281:17228-37.

50. Welter-Stahl L, da Silva CM, Schachter J, Persechini PM, Souza HS, Ojcius DM, et al. Expression of purinergic receptors and modulation of P2X7 function by the inflammatory cytokine IFNgamma in human epithelial cells. Biochim Biophys Acta 2009;1788:1176-87.

51. Ghiringhelli F, Apetoh L, Tesniere A, Aymeric L, Ma Y, Ortiz C, et al. Activation of the NLRP3 inflammasome in dendritic cells induces IL-1beta-dependent adaptive immunity against tumors. Nat Med 2009; $15: 1170-8$

52. Fuller SJ, Stokes L, Skarratt KK, Gu BJ, Wiley JS. Genetics of the P2X7 receptor and human disease. Purinergic Signal 2009;5:257-62.

53. Ferrari D, Gorini S, Callegari G, la Sala A. Shaping immune responses through the activation of dendritic cells' P2 receptors. Purinergic Signal 2007;3:99-107.

54. Coutinho-Silva R, Robson T, Beales PE, Burnstock G. Changes in expression of $\mathrm{P} 2 \mathrm{X} 7$ receptors in NOD mouse pancreas during the development of diabetes. Autoimmunity 2007;40:108-16.

55. Goncalves RG, Gabrich L, Rosario A Jr, Takiya CM, Ferreira ML, Chiarini LB, et al. The role of purinergic $\mathrm{P} 2 \mathrm{X} 7$ receptors in the inflammation and fibrosis of unilateral ureteral obstruction in mice. Kidney Int 2006;70:1599-606.

56. Oliveira SD, Coutinho-Silva R, Silva CL. Endothelial P2X7 receptors' expression is reduced by schistosomiasis. Purinergic Signal $2013 ; 9: 81-9$

57. Marques-da-Silva C, Chaves MM, Castro NG, Coutinho-Silva R, Guimaraes MZ. Colchicine inhibits cationic dye uptake induced by ATP in P2X2 and P2X7 receptor-expressing cells: Implications for its therapeutic action. Br J Pharmacol 2011;163:912-26.

58. Arulkumaran N, Unwin RJ, Tam FW. A potential therapeutic role for
$\mathrm{P} 2 \mathrm{X} 7$ receptor $(\mathrm{P} 2 \mathrm{X} 7 \mathrm{R})$ antagonists in the treatment of inflammatory diseases. Expert Opin Investig Drugs 2011;20:897-915.

59. Elliott MR, Chekeni FB, Trampont PC, Lazarowski ER, Kadl A, Walk SF, et al. Nucleotides released by apoptotic cells act as a find-me signal to promote phagocytic clearance. Nature 2009;461:282-6.

60. McDonald B, Pittman K, Menezes GB, Hirota SA, Slaba I, Waterhouse CC, et al. Intravascular danger signals guide neutrophils to sites of sterile inflammation. Science 2010;330:362-6.

61. Scheuplein F, Schwarz N, Adriouch S, Krebs C, Bannas P, Rissiek $\mathrm{B}$, et al. NAD+ and ATP released from injured cells induce P2X7-dependent shedding of CD62L and externalization of phosphatidylserine by murine T cells. J Immunol 2009;182:2898-908.

62. Deaglio S, Robson SC. Ectonucleotidases as regulators of purinergic signaling in thrombosis, inflammation, and immunity. Adv Pharmacol 2011;61:301-32

63. Robson SC, Sevigny J, Zimmermann H. The E-NTPDase family of ectonucleotidases: Structure function relationships and pathophysiological significance. Purinergic Signal 2006;2:409-30.

64. Zimmermann H, Zebisch M, Strater N. Cellular function and molecular structure of ecto-nucleotidases. Purinergic Signal $2012 ; 8: 437-502$

65. Yegutkin GG. Nucleotide- and nucleoside-converting ectoenzymes: Important modulators of purinergic signalling cascade. Biochim Biophys Acta 2008;1783:673-94.

66. Zimmermann H. Ectonucleotidases in the nervous system. Novartis Found Symp 2006;276:113-28.

67. Hicks-Berger CA, Chadwick BP, Frischauf AM, Kirley TL. Expression and characterization of soluble and membrane-bound human nucleoside triphosphate diphosphohydrolase 6 (CD39L2). J Biol Chem 2000;275:34041-5.

68. Mulero JJ, Yeung G, Nelken ST, Ford JE. CD39-L4 is a secreted human apyrase, specific for the hydrolysis of nucleoside diphosphates. J Biol Chem 1999;274:20064-7.

69. Bigonnesse F, Levesque SA, Kukulski F, Lecka J, Robson SC, Fernandes $\mathrm{MJ}$, et al. Cloning and characterization of mouse nucleoside triphosphate diphosphohydrolase-8. Biochemistry 2004;43:5511-9.

70. Antonioli L, Pacher P, Vizi ES, Hasko G. CD39 and CD73 in immunity and inflammation. Trends Mol Med 2013;19:355-67.

71. Levesque SA, Kukulski F, Enjyoji K, Robson SC, Sevigny J. NTPDase1 governs P2X7-dependent functions in murine macrophages. Eur J Immunol 2010;40:1473-85.

72. Zanin RF, Braganhol E, Bergamin LS, Campesato LF, Filho AZ, Moreira JC, et al. Differential macrophage activation alters the expression profile of NTPDase and ecto-5'-nucleotidase. PLoS One 2012;7:e31205.

73. Theatre E, Frederix K, Guilmain W, Delierneux C, Lecut C, Bettendorff L, et al. Overexpression of CD39 in mouse airways promotes bacteria-induced inflammation. J Immunol 2012;189:1966-74.

74. Coutinho-Silva R, Correa G, Sater AA, Ojcius DM. The P2X(7) receptor and intracellular pathogens: A continuing struggle. Purinergic Signal 2009;5:197-204.

75. Leal DB, Streher CA, Bertoncheli Cde M, Carli LF, Leal CA, da Silva JE, et al. HIV infection is associated with increased NTPDase

Biomed J Vol. 37 No. 4

July - August 2014 
activity that correlates with CD39-positive lymphocytes. Biochim Biophys Acta 2005;1746:129-34.

76. Schulze Zur Wiesch J, Thomssen A, Hartjen P, Toth I, Lehmann C, Meyer-Olson D, et al. Comprehensive analysis of frequency and phenotype of T regulatory cells in HIV infection: CD39 expression of FoxP3 + T regulatory cells correlates with progressive disease. J Virol 2011;85:1287-97.

77. Kas-Deelen AM, Bakker WW, Olinga P, Visser J, de Maar EF, van Son WJ, et al. Cytomegalovirus infection increases the expression and activity of ecto-ATPase (CD39) and ecto-5'nucleotidase (CD73) on endothelial cells. FEBS Lett 2001;491:21-5.

78. Crane JK, Olson RA, Jones HM, Duffey ME. Release of ATP during host cell killing by enteropathogenic E. coli and its role as a secretory mediator. Am J Physiol Gastrointest Liver Physiol 2002;283:G74-86.

79. Sansom FM, Newton HJ, Crikis S, Cianciotto NP, Cowan PJ, d'Apice AJ, et al. A bacterial ecto-triphosphate diphosphohydrolase similar to human CD39 is essential for intracellular multiplication of Legionella pneumophila. Cell Microbiol 2007;9:1922-35.

80. Zebisch M, Krauss M, Schafer P, Lauble P, Strater N. Crystallographic Snapshots along the Reaction Pathway of Nucleoside Triphosphate Diphosphohydrolases. Structure 2013;21:1460-75.

81. Yilmaz O, Yao L, Maeda K, Rose TM, Lewis EL, Duman M, et al. ATP scavenging by the intracellular pathogen Porphyromonas gingivalis inhibits P2X7-mediated host-cell apoptosis. Cell Microbiol 2008;10:863-75

82. Dar HH, Prasad D, Varshney GC, Chakraborti PK. Secretory nucleoside diphosphate kinases from both intra- and extracellular pathogenic bacteria are functionally indistinguishable. Microbiology 2011;157:3024-35.

83. de Souza MC, de Assis EA, Gomes RS, Marques da Silva Ede A, Melo MN, Fietto JL, et al. The influence of ecto-nucleotidases on Leishmania amazonensis infection and immune response in C57B/6 mice. Acta Trop 2010;115:262-9.

84. Sansom FM, Robson SC, Hartland EL. Possible effects of microbial ecto-nucleoside triphosphate diphosphohydrolases on host-pathogen interactions. Microbiol Mol Biol Rev 2008;72:765-81.

85. Tasca T, Bonan CD, De Carli GA, Sarkis JJ, Alderete JF. Heterogeneity in extracellular nucleotide hydrolysis among clinical isolates of Trichomonas vaginalis. Parasitology 2005;131:71-8.

86. Santos RF, Possa MA, Bastos MS, Guedes PM, Almeida MR, Demarco R, et al. Influence of Ecto-nucleoside triphosphate diphosphohydrolase activity on Trypanosoma cruzi infectivity and virulence. PLoS Negl Trop Dis 2009;3:e387.

87. Goding JW, Grobben B, Slegers H. Physiological and pathophysiological functions of the ecto-nucleotide pyrophosphatase/ phosphodiesterase family. Biochim Biophys Acta 2003;1638:1-19.

88. Stefan C, Jansen S, Bollen M. NPP-type ectophosphodiesterases: Unity in diversity. Trends Biochem Sci 2005;30:542-50.
89. Baroja-Mazo A, Pelegrin P. Modulating P2X7 Receptor Signaling during Rheumatoid Arthritis: New Therapeutic Approaches for Bisphosphonates. J Osteoporos 2012;2012:408242.

90. Pelegrin P, Surprenant A. Dynamics of macrophage polarization reveal new mechanism to inhibit IL-1beta release through pyrophosphates. EMBO J 2009;28:2114-27.

91. Lopez-Castejon G, Baroja-Mazo A, Pelegrin P. Novel macrophage polarization model: From gene expression to identification of new anti-inflammatory molecules. Cell Mol Life Sci 2011;68:3095-107.

92. Vuaden FC, Savio LE, Bastos CM, Bogo MR, Bonan CD. Adenosine $\mathrm{A}(2 \mathrm{~A})$ receptor agonist (CGS-21680) prevents endotoxin-induced effects on nucleotidase activities in mouse lymphocytes. Eur J Pharmacol 2011;651:212-7.

93. Vuaden FC, Savio LE, Ramos DB, Casali EA, Bogo MR, Bonan CD Endotoxin-induced effects on nucleotide catabolism in mouse kidney. Eur J Pharmacol 2012;674:422-9.

94. Souza Vdo C, Schlemmer KB, Noal CB, Jaques JA, Bagatini MD, Pimentel VC, et al. Purinergic system ecto-enzymes participate in the thromboregulation of patients with indeterminate form of Chagas disease. Purinergic Signal 2012;8:753-62.

95. Vuaden FC, Furstenau CR, Savio LE, Sarkis JJ, Bonan CD Endotoxemia alters nucleotide hydrolysis in platelets of rats. Platelets 2009;20:83-9.

96. Hama K, Aoki J, Fukaya M, Kishi Y, Sakai T, Suzuki R, et al. Lysophosphatidic acid and autotaxin stimulate cell motility of neoplastic and non-neoplastic cells through LPA1. J Biol Chem 2004;279:17634-9.

97. Kishi Y, Okudaira S, Tanaka M, Hama K, Shida D, Kitayama J, et al. Autotaxin is overexpressed in glioblastoma multiforme and contributes to cell motility of glioblastoma by converting lysophosphatidylcholine to lysophosphatidic acid. J Biol Chem 2006;281:17492-500.

98. Buffon A, Casali EA, Cardoso VV, Zerbini LF, Robson SC, Sarkis JJ, et al. Differential expression of nucleotide pyrophosphatase/ phosphodiesterases by Walker 256 mammary cancer cells in solid tumors and malignant ascites. Life Sci 2010;86:435-40.

99. Zimmermann H. 5'-Nucleotidase: Molecular structure and functional aspects. Biochem J 1992;285:345-65.

100. Airas L. CD73 and adhesion of B-cells to follicular dendritic cells. Leuk Lymphoma 1998;29:37-47.

101. Resta R, Yamashita Y, Thompson LF. Ecto-enzyme and signaling functions of lymphocyte CD73. Immunol Rev 1998;161:95-109.

102. Eltzschig HK, Thompson LF, Karhausen J, Cotta RJ, Ibla JC, Robson SC, et al. Endogenous adenosine produced during hypoxia attenuates neutrophil accumulation: Coordination by extracellular nucleotide metabolism. Blood 2004;104:3986-92.

103. Hasko G, Pacher P. Regulation of macrophage function by adenosine. Arterioscler Thromb Vasc Biol 2012;32:865-9. 